\title{
Multifunctional Ligand Approach: Search for Effective Therapy Against Alzheimer's Disease
}

\author{
Anna Pasieka • Dawid Panek • Barbara Malawska \\ Department of Physicochemical Drug Analysis, Faculty of Pharmacy, Jagiellonian \\ University Medical College, Kraków, Poland
}

Author for correspondence: Barbara Malawska, Department of Physicochemical Drug Analysis, Faculty of Pharmacy, Jagiellonian University Medical College, Kraków 30-688, Poland.Email: mfmalaws@cyf-kr.edu.pl

Doi: https://doi.org/10.36255/exonpublications.alzheimersdisease.2020.ch11

\begin{abstract}
Alzheimer's disease is a progressive, incurable, and complex neurodegenerative disease. Currently, an effective treatment that can slow down or stop the damage and death of neurons, which is a characteristic of Alzheimer's disease, is lacking. Taking into account the complex nature of the disease, a multitarget design approach has been developed for the production of new potential anti-AD agents. The goal of this approach is to create a single molecule that can interact selectively with several desired molecular targets relevant to the disease. This strategy was successfully developed two decades ago and has been improved in recent years. This chapter describes the progress made in the discovery and design of selected multitargeted drugs based on molecular targets, which can be used for treating Alzheimer's disease. The most promising among these drugs are the molecules having properties that are valuable not only in the symptomatic therapy but also in the causal treatment of the disease. The main hypotheses of Alzheimer's disease, such as $\beta$-amyloid $(A \beta)$, tau, and cholinergic, suggest that compounds capable of inhibiting the aggregation of neurotoxic $A \beta$-amyloid peptide and tau protein, and improving the cholinergic neurotransmission, may possess such properties.
\end{abstract}

In: Alzheimer's Disease: Drug Discovery. Huang X (Editor). Exon Publications, Brisbane, Australia. ISBN: 978-0-6450017-0-9; Doi: https://doi.org/10.36255/exonpublications.alzheimersdisease.2020 Copyright: The Authors.

License: This open access article is licenced under Creative Commons Attribution-NonCommercial 4.0 International (CC BY-NC 4.0) https://creativecommons.org/licenses/by-nc/4.0/ 
Examples of such multifunctional molecules, which have been recently reported in the literature, are presented in this chapter.

Keywords: Alzheimer's disease; disease-modifying strategies; multimodal compounds; polypharmacology; symptomatic strategies

\section{INTRODUCTION}

Alzheimer's disease (AD) is a progressive, incurable, and complex neurodegenerative disorder. The two main neuropathological hallmarks of AD are extracellular amyloid plaques composed of $\beta$-amyloid $(A \beta)$, and intracellular neurofibrillary tangles (NFTs) containing the tau protein, leading to nerve cell death. In addition, AD is characterized by a low level of the neurotransmitter acetylcholine and loss of cholinergic neurons, excitotoxicity, impairment of other neurotransmitter systems, extensive oxidative stress, chronic neuroinflammation, mitochondrial dysfunction, calcium and metal dyshomeostasis, and other factors (1). This complex and unclear pathogenesis of AD has led to the creation of several theories. The oldest one is the cholinergic hypothesis, followed by others such as the $A \beta$ hypothesis, the tau hypothesis, the oxidative stress theory, the metal imbalance theory, the mitochondrial cascade, and the inflammation hypothesis were developed. The available AD therapy is based only on medications that are capable of treating the cognitive symptoms: three cholinesterase inhibitors (donepezil, rivastigmine, and galantamine) and one $\mathrm{N}$-methyl-D-aspartic acid (NMDA) receptor antagonist (memantine). Currently, an effective treatment that may slow down or stop the damage and death of neurons in $\mathrm{AD}$ is lacking.

Complex diseases such as $\mathrm{AD}$ require a more intricate treatment $(2,3)$, and hence, agents acting on only one particular target or modulating only one process are not sufficient. This problem can be overcome by two possible approaches. The first, polypharmacy, involves combination therapies with the use of two or more drugs (4). An alternative way is to use multifunctional compounds that exhibit many effects by interacting with more than one biological target $(5,6)$. Such molecules, which are referred to as multifunctional or multidirectional compounds, multitargeted ligands (MTLs), or multitarget-directed ligands (MTDLs), provide additive or synergistic effects, called polypharmacology (7).

The issues related to the use of combination therapies for $\mathrm{AD}$ have been recently described by Cummings et al. (8). Pharmacodynamic combination therapies are based on two or more symptomatic agents that can improve the behavioral and cognitive symptoms of AD and/or disease-modifying therapies (DMTs) that affect the causes of the disease. In 2014, Namzaric, a combination of two symptomatic medications - the cholinesterase inhibitor, donepezil and the NMDA receptor antagonist, memantine-was approved for the treatment of AD patients with moderate-to-severe dementia (9). Currently, various clinical trials are ongoing on combination therapies involving a standard-of-care medication like a cholinesterase inhibitor or memantine combined with another agent. Selected add-on clinical trials of combination treatment for $\mathrm{AD}$, using a small molecule with a standard-of-care medication, are presented in Table 1. 


\section{TABLE 1 Selected add-on clinical trials of combination treatment for AD using a small molecule with a standard-of-care medication}

\begin{tabular}{|c|c|c|c|c|}
\hline Agent & Biological target & Phase & Baseline Therapy & Clinical trials \\
\hline Masitinib & $\begin{array}{l}\text { Selective tyrosine kinase } \\
\text { inhibitor }\end{array}$ & III & $\begin{array}{l}\text { Rivastigmine and/or } \\
\text { memantine }\end{array}$ & NCT01872598 \\
\hline Telmisartan & $\begin{array}{l}\text { Angiotensin II receptor } \\
\text { antagonist }\end{array}$ & II & $\begin{array}{l}\text { AChE inhibitor and/or } \\
\text { memantine }\end{array}$ & NCT02085265 \\
\hline Saracatinib & Src/Abl kinase family inhibitor & II & $\begin{array}{l}\text { AChE inhibitor and/or } \\
\text { memantine }\end{array}$ & NCT02167256 \\
\hline UE2343 & $\begin{array}{l}\beta \text {-Hydroxysteroid } \\
\quad \text { dehydrogenase inhibitor }\end{array}$ & II & $\begin{array}{l}\text { AChE inhibitor and/or } \\
\text { memantine }\end{array}$ & NCT02727699 \\
\hline ANAVEX2-73 & Sigma-1 chaperone agonist & II & $\begin{array}{l}\text { AChE inhibitor and/or } \\
\text { memantine }\end{array}$ & NCT02244541 \\
\hline Neflamapimod & P38 MAPK alfa inhibitor & II & $\begin{array}{l}\text { AChE inhibitor or } \\
\text { memantine }\end{array}$ & NCT03402659 \\
\hline CT1812 & $\begin{array}{l}\text { Antagonist of the sigma- } 2 \\
\text { receptor }\end{array}$ & II & $\begin{array}{l}\text { AChE inhibitor or } \\
\text { memantine }\end{array}$ & NCT02907567 \\
\hline Idalopirdine & 5- $\mathrm{HT}_{6}$ receptor antagonist & III & $\begin{array}{l}\text { Donepezil or donepezil } \\
\text { and memantine }\end{array}$ & NCT01955161 \\
\hline Citalopram & $\begin{array}{l}\text { Selective serotonin reuptake } \\
\text { inhibitor }\end{array}$ & III & $\begin{array}{l}\text { AChE inhibitor and/or } \\
\text { memantine }\end{array}$ & NCT00898807 \\
\hline Rasagiline & MAO-B inhibitor & II & $\begin{array}{l}\text { AChE inhibitor or } \\
\text { memantine }\end{array}$ & NCT02359552 \\
\hline Piromelatine & $\begin{array}{l}\text { Melatonin and serotonin } \\
\text { receptor agonist }\end{array}$ & II & $\begin{array}{l}\text { AChE inhibitor or } \\
\text { memantine }\end{array}$ & NCT02615002 \\
\hline
\end{tabular}

$\mathrm{AD}$, Alzheimer's disease; AChE, acetylcholinesterase; MAO, monoamine oxidase; MAPK, mitogen-activated protein kinase.

\section{MULTITARGET LIGANDS APPROACH}

Combination therapy has some disadvantages resulting from the possible accumulation of drug side effects, pharmacokinetic complexity, drug-drug interactions, and decreased compliance. Moreover, older patients might feel that using one tablet is more convenient than using two or more. Multifunctional compounds are free of the above-mentioned disadvantages. Since these agents can be considered as a form of multicomponent therapy, the creation of new molecules is based on similar principles. Multifunctional agents can be designed by combing two or more structures of active agents or their pharmacophore fragments that interact with the desired targets. Possible strategies for designing multifunctional agents include combining molecules that can interact with two symptomatic targets or symptomatic targets and disease-modifying targets or with two diseasemodifying targets. The targets of DMT are neurotoxic aggregates of A $\beta$ and tau 
protein, as well as various processes associated with neuroprotection or neuroinflammation. The targets of symptomatic therapy are the cholinergic system, including acetylcholinesterase (AChE) and butyrylcholinesterase (BuChE) enzymes, NMDA neurotransmission, G protein-coupled receptors (GPCRs), and monoamine oxidase (MAO) enzymes (Table 2).

A multitarget design approach was successfully developed two decades ago and has been improved in recent years. There are basically three ways to combine pharmacophores to form an MTL structure, which can interact with appropriate biological targets (10). The simplest way is to connect two pharmacophores through a linker. Another way is to combine two pharmacophore fragments without a linker, forming condensed molecules. The third and best way is to create merged pharmacophores that result in small molecules with low molecular weight and thus with good drug-like properties. Over the years, various potential multifunctional anti-AD agents have been designed, synthesized, and developed (11-13). Based on the structures of currently used anti-AD drugs or their

\section{TABLE 2 Therapeutic strategies of AD applied for the creation of multifunctional agents}

\begin{tabular}{|c|c|c|}
\hline $\begin{array}{l}\text { Therapeutic strategies } \\
\text { for } A D \text { treatment }\end{array}$ & Target for AD treatment & Agents \\
\hline \multirow[t]{3}{*}{ Disease modifying therapies } & $\mathrm{A} \beta$ aggregates & $\begin{array}{l}\beta \text {-Secretase inhibitor } \\
\text { A } \beta \text { aggregation inhibitor } \\
\text { Metal chelator }\end{array}$ \\
\hline & Tau aggregates & $\begin{array}{l}\text { GSK-3 } \beta \text { inhibitor } \\
\text { Tau aggregation inhibitor }\end{array}$ \\
\hline & $\begin{array}{l}\text { Neuroinflammation } \\
\text { Neuroprotection } \\
\text { Various }\end{array}$ & $\begin{array}{l}\text { COX-2 inhibitor, LOX inhibitor, } \\
\text { Antineuroinflammatory agent, } \\
\text { S1R modulator, } \\
\text { Antioxidant agent, } \\
\text { PDE4 inhibitor }\end{array}$ \\
\hline \multirow[t]{6}{*}{ Symptomatic therapies } & Cholinergic neurotransmission & $\begin{array}{l}\text { AChE inhibitor } \\
\text { BuChE inhibitor }\end{array}$ \\
\hline & NMDA neurotransmission & NMDA receptor antagonist \\
\hline & $\begin{array}{l}\text { GPCRs } \\
\text { Serotonin receptor }\end{array}$ & $\begin{array}{l}\text { 5- } \mathrm{HT}_{4} \text { receptor agonist } \\
\text { 5- } \mathrm{HT}_{6} \text { receptor antagonist }\end{array}$ \\
\hline & $\begin{array}{l}\text { GPCRs } \\
\text { Histamine receptor }\end{array}$ & $\begin{array}{l}\mathrm{H}_{3} \text { receptor antagonist/inverse } \\
\text { agonist }\end{array}$ \\
\hline & $\begin{array}{l}\text { GPCRs } \\
\text { Cannabinoid receptor }\end{array}$ & $\begin{array}{l}\mathrm{CB}_{1} \text { receptor antagonist } \\
\mathrm{CB}_{2} \text { receptor agonist } \\
\text { FAAH enzyme }\end{array}$ \\
\hline & Oxidative damage & $\begin{array}{l}\text { MAO-A inhibitor } \\
\text { MAO-B inhibitor }\end{array}$ \\
\hline
\end{tabular}

$\mathrm{AD}$, Alzheimer's disease; AChE, acetylcholinesterase; BuChE, butyrylcholinesterase; COX, cyclooxygenase; FAAH, fatty acid amide hydrolase; GPCR, G protein-coupled receptors; GSK, glycogen synthase kinase; LOX, lypoxygenase; MAO, monoamine oxidase; NMDA, N-methyl-D-aspartic acid; PDE4, phosphodiesterase 4. 
pharmacophoric fragments, multimodal compounds are produced. Thus, ligands containing fragments of tacrine (as a strong inhibitor of cholinesterases), donepezil, or rivastigmine are the most numerous. Of these, only ladostigil has entered phase II/III clinical trials in patients with mild cognitive impairment. Its structure represents a merged pharmacophore, which is formed by combining a propargylamine moiety derived from an MAO-A/B inhibitor rasagiline with a pharmacophoric carbamyl moiety derived from rivastigmine. Ladostigil is a dual AChE/BuChE and a brain-selective $\mathrm{MAO}-\mathrm{A} / \mathrm{B}$ inhibitor possessing in vivo neuroprotective properties (14) and, as such, is an example of a multifunctional agent created by combining two pharmacophores that act on the symptomatic targets of AD.

Among the various multifunctional agents, the largest group that focuses on the targets of symptomatic therapy is cholinesterase inhibitors combined with other targets (15). Dual binding site cholinesterase inhibitors capable of interacting with the catalytic active site and the peripheral anionic binding site of AChE can inhibit $\mathrm{A} \beta$ aggregation. Based on this action, many such ligands were obtained, which showed potency toward both symptomatic targets (AChE/BuChE) and disease-modifying targets ( $\beta$ aggregation) (16-20). Herein, the recent advances made in the design of multifunctional agents for AD treatment based on molecular targets and selected examples of novel multimodal ligands are presented.

\section{MULTIFUNCTIONAL AGENTS FOCUSING ON DISEASE- MODIFYING TARGETS: A $\beta$ AND OTHERS}

The $A \beta$ hypothesis assumes that the primary cause of neuron loss is the formation of senile plaques due to abnormal processing of amyloid precursor protein (APP) (21). The key role in this process is played by the $\beta$-secretase enzyme (BACE-1, $A \beta$ precursor protein-cleaving enzyme 1 ), which together with $\gamma$-secretase cleaves APP, producing A $\beta$ peptides consisting of 38-42 amino acids. Because of their fibrillogenic and hydrophobic nature, A $\beta$ peptides accumulate easily. These peptide aggregates induce oxidative stress, neuroinflammation, hyperphosphorylation, and the aggregation of tau protein, ultimately resulting in loss of neurons and dementia. Based on this theory, some biological disease-modifying targets have been identified and are used in the search for new anti-AD agents. Inhibition of BACE- 1 and amyloid aggregation is considered as the most important objective of these agents. Currently, 38 (29\%) A $\beta$-targeting agents are undergoing clinical trials, of which four BACE-1 inhibitors are gaining continued interest as biological targets in the field of drug discovery and development (22). BACE-1 inhibition has also been applied for the generation of MTDLs having other beneficial properties.

\section{BACE-1 inhibitors with other properties}

The structure of donepezil is widely used as a pharmacophoric moiety for developing multifunctional agents (19). Examples of compounds formed using the donepezil structure are N-benzylpiperidine analogs acting as BACE-1 and AChE inhibitors with antioxidant and antiaggregating properties, which were described 
by Sharma et al. (23). As a core group, N-benzylpiperidine moiety present in donepezil and capable of inhibiting BACE-1 was selected. Virtual screening led to the emergence of the hit compound SEW06622. Based on its structure, a series of new anti-AD agents was designed. The compounds differed in the substitution of benzylamine and the presence of a double bond close to the nitrogen atom. The design of these compounds is presented in Figure 1. Among them, compound $\mathbf{1}$<smiles>COc1cc2c(cc1OC)C(=O)C(CC1CCN(Cc3ccccc3)CC1)C2</smiles>

hit compound SEW06622

$h \mathrm{BACE}-1 \mathrm{IC}_{50}=6.3 \mu \mathrm{M}$

$h A C h E I C_{50}>15 \mu \mathrm{M}$

$h$ BuChE IC $50>30 \mu \mathrm{M}$

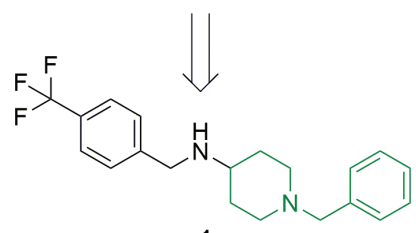

1

$h \mathrm{BACE}-1 \mathrm{IC} \mathrm{C}_{50}=0.22 \mu \mathrm{M}$

$h A C h E I_{50}=0.11 \mu \mathrm{M}$

$h$ BuChE IC ${ }_{50}=3.0 \mu \mathrm{M}$

in vivo efficacy

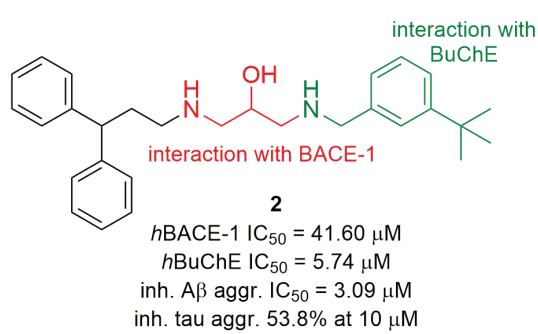

tetrahydroisoquinoline moiety<smiles>COc1ccc2nc(-c3cccc(N4CCc5ccccc5C4)n3)[nH]c2c1</smiles>

3

hBACE- 1 inh. $65.7 \%$ at $20 \mu \mathrm{M}$

anti-neuroinflammation $\mathrm{NO} \mathrm{IC}_{50}=5.07 \mu \mathrm{M}$ neuroprotection $91.8 \%$ cell survived at $5 \mu \mathrm{M}$ reduce the level of TNF- $\alpha$ and IL-1 $\beta$ BBB-PAMPA $(+)$

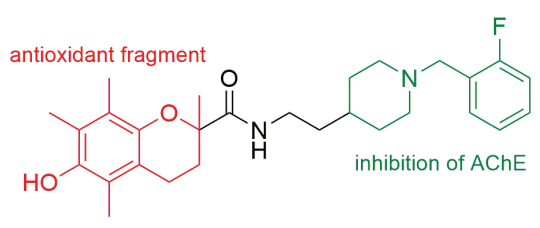

4

inh. of self- and $\mathrm{Cu}^{2+}$-induced $\mathrm{A} \beta$ aggr. antioxidant, copper chelation properties $h \mathrm{AChE} I \mathrm{IC}_{50}=0.54 \mu \mathrm{M}$ $h$ BuChE IC ${ }_{50}=5.97 \mu \mathrm{M}$ $h \mathrm{MAO}-\mathrm{A} \mathrm{IC}_{50}=4.4 \mu \mathrm{M}$ $h \mathrm{MAO}-\mathrm{B} I \mathrm{C}_{50}=4.3 \mu \mathrm{M}$ in vivo efficacy

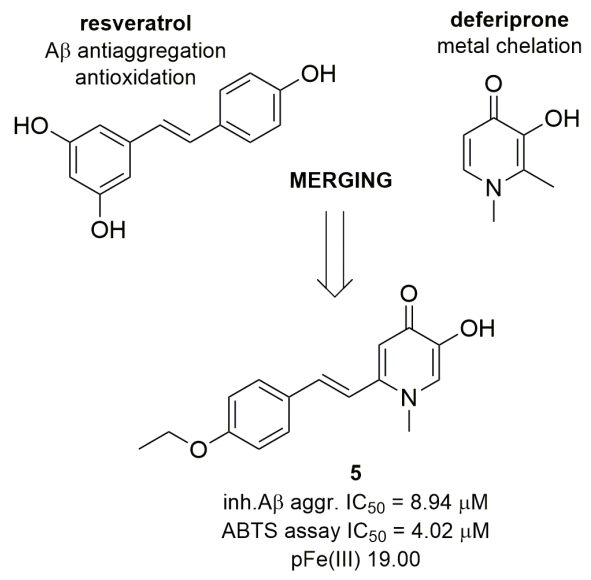

Figure 1. Multifunctional agents focusing on disease-modifying targets: BACE-1, A $\beta$, and others. 
was found to be the most promising. Besides inhibiting both BACE-1 and AChE enzymes with $\mathrm{IC}_{50}$ values in the submicromolar range, it showed blood-brain barrier (BBB) permeability in the parallel artificial membrane permeability assay (PAMPA) and inhibited self-induced and AChE-induced A $\beta$ aggregation, while proving to be safe in SH-SY5Y neuroblastoma cell lines at a concentration of up to $80 \mu \mathrm{M}$. Most importantly, it alleviated cognitive impairment in rat models of scopolamine-induced amnesia and by continuous intracerebroventricular infusion of a pathogenic dose of $A \beta$ peptides. In addition, compound $\mathbf{l}$ displayed good pharmacokinetic parameters after oral administration. Therefore, it can be considered as a potential drug candidate for AD treatment (23).

The approach to obtain disease-modifying and symptomatic multifunctional ligands inspired the design and synthesis of a group of 1-benzylamino-2hydroxyalkyl derivatives (24). The new multifunctional agents contained substituted benzylamine, responsible for inhibiting BuChE, connected to aromatic fragments: benzyl, phenyl, and benzhydryl through a 2-hydroxyethyleneamine linker. This linker was suggested to confer the agents with BACE-1 inhibitory activity. Among these ligands, the diphenylpropylamine derivative 2 (Figure 1) was the most interesting, which was capable of inhibiting BACE-1 and BuChE, as well as $A \beta$ and tau aggregation. Due to its broad biological profile, it is regarded as a potential multifunctional compound (24).

\section{Multifunctional agents combining $\mathrm{A} \boldsymbol{\beta}$ antiaggregation effects with other activities}

A series of tetrahydroisoquinoline-benzimidazole derivatives was developed, which represent multifunctional anti-AD agents focusing only on the disease-modifying effects (25). To design this group, two well-known pharmacophores, benzimidazole, present in BACE-1 and inflammation inhibitors, and a tetrahydroisoquinoline moiety possessing anti-inflammatory, antioxidation, and neuroprotection properties, were chosen. Benzene or pyridine ring was used as a linker. Among the obtained derivatives, compound 3 showed the most balanced profile (Figure 1). It inhibited nitric oxide (NO) production in lipopolysaccharide (LPS)induced BV2 microglia cells with an $\mathrm{IC}_{50}$ value of $5.07 \mu \mathrm{M}$ and BACE-1 activity by $65.7 \%$ at a concentration of $20 \mu \mathrm{M}$. Additionally, it showed a strong neuroprotective effect against glutamate-induced cell death at $5 \mu \mathrm{M}$ (91.8\% cell viability) and reduced the level of proinflammatory cytokines such as TNF- $\alpha$ and IL-1 $\beta$. Furthermore, the ability to penetrate the BBB demonstrated that compound 3 is a promising multiple anti-AD ligand.

Suppressing the formation of senile plaques is feasible not only by the inhibition of enzymes involved in the pathological $A \beta$ cascade but also by direct inhibition of $A \beta$ aggregation. Kong's group (26) designed compounds that displayed this property as well as other anti-AD activities, based on two structures: donepezil and Trolox, an antioxidative analog of vitamin E. The Trolox fragment was fused with a differently substituted N-benzylpiperidine moiety derived from donepezil by an amide bond. The designed compounds were supposed to bind to both active sites of $\mathrm{AChE}$ and inhibit $\mathrm{AChE}, \mathrm{A} \beta$ aggregation, and MAOs, while also acting as antioxidants. The biological evaluation of the effect of these compounds on all proposed targets revealed that compound 4 , which had a fluor 
atom in position 2 of benzene ring, was a promising MTDL (Figure 1). This compound inhibited both cholinesterases $\left(\mathrm{IC}_{50} h \mathrm{AChE}=0.54 \mu \mathrm{M}, \mathrm{IC}_{50} h \mathrm{huChE}=\right.$ $5.97 \mu \mathrm{M})$. Moreover, it displayed nonselective inhibitory activity against MAO-A and MAO-B at a micromolar range. Its antioxidant property compared to Trolox was confirmed in three different experiments. Furthermore, compound 4 exhibited a metal-chelating effect, especially with copper ions, which are associated with AD pathogenesis. The results of self-induced and metal-induced A $\beta$ aggregation assays also indicated that compound 4 can inhibit both types of A $\beta$ aggregation. The promising outcomes of the in vitro assays were translated successfully to in vivo experiments, in which multifunctional ligand 4 was found to significantly improve cognitive decline in scopolamine-, D-galactose-, and $\mathrm{AlCl}_{3}$-induced memory deficit models. All these results suggested that this compound is an excellent anti-AD candidate.

Another antioxidant and antiaggregating molecule that can serve as a multifunctional compound is the well-known natural derivative resveratrol. For designing new hybrid structures, deferiprone, metal-chelating drug was used (27). These two structures were merged by replacing one of the aromatic rings of resveratrol by deferiprone moiety (Figure 1). Among the newly synthesized hybrids, compound 5 possessing an ethoxy group at position 4 showed triple anti-AD functions-inhibition of A $\beta$ aggregation, antioxidation, and metal chelation. Such properties make it a potential disease-modifying drug candidate.

\section{MULTIFUNCTIONAL AGENTS FOCUSING ON DISEASE- MODIFYING TARGETS: TAU PROTEIN AND OTHERS}

Besides the presence of senile plaques in the brain of patients suffering from AD, the occurrence of NFTs consisting of hyperphosphorylated tau protein aggregates is discerned as the second hallmark of the disease. Based on this observation, the tau hypothesis was formulated to explain the development of AD (28). Tau is a microtubule-associated protein, which, in the physiological condition, stabilizes the microtubules and takes part in axonal transport. During the pathological process, kinases, especially glycogen synthase kinase (GSK-3 $\beta$ ) and GSK-3 $\alpha$, excessively phosphorylate this protein, resulting in a loss of function. Hyperphosphorylated tau proteins aggregate and easily create intracellular lesions-primarily paired helical filaments and further NFTs. As indicated by the tau theory, the presence of these aggregates contributes to all the processes related to the $\mathrm{AD}$ pathomechanism leading to dementia, including $\mathrm{A} \beta$ aggregation. Therefore, in drug discovery and development, the tau-centered approaches, which involve the interaction with kinases, mainly the GSK-3 $\beta$ enzyme, and the direct inhibition of tau aggregation process, are especially important (29).

\section{Tau and $A \beta$ inhibitors}

One of the valuable strategies applied in the search of new anti-AD agents is the dual inhibition of $A \beta$ and tau aggregation for reducing simultaneously the level of both lesions. An example of these agents is 1,2,3,4-tetrahydro-1-acridone 
analogs, which were designed by combining the structure of tacrine with quinolone moiety, and the antiaggregating compound cinnamaldehyde containing $\alpha, \beta$-unsaturated carbonyl fragment (30). Among the derivatives that differed in the length of linker, degree of saturation, substitution of cinnamaldehyde moiety, and methylation of the nitrogen atom of tacrine, five compounds inhibited $A \beta_{1-42}$ and tau aggregation by $84.7-99.5 \%$ and $71.2-101.8 \%$, respectively, at the screening concentration of $20 \mu \mathrm{M}$. All these compounds had a quaternary amine considered crucial for the observed inhibitory activities. Compound 6 with a naphthalene residue (Figure 2), which was identified as a noncovalent inhibitor of both neurotoxic proteins and predicted to penetrate the BBB as well as prevent tau aggregation in living cells, was selected as the most promising dual agent.

Due to its rich biological properties, the curcumin scaffold is highly preferred in the design of multiple antiaggregation agents. It is a natural polyphenol, reported to have antioxidant, antiaggregating, and anti-inflammatory activities, and is used as a yellow spice. Because of its poor pharmacokinetic parameters, especially bioavailability, the scaffold is not applied in the treatment of AD. However, its structure was included in a series of potential multifunctional ligands (31). Compound 7 (PE859) is a perfect example of such ligands (32) (Figure 2), which was found to display higher dual antiaggregating properties compared to the parent compound. Moreover, it penetrated the BBB, improved memory in vivo, reduced the amount of both aggregated lesions in mice brains, and showed a promising pharmacokinetic profile.

Dual $A \beta$ and tau antiaggregating properties were also combined with anticholinesterase activity in order to achieve disease-modifying and symptomatic effects. However, it should be noted that such hybrid molecules were designed as dual binding site cholinesterase inhibitors with potential $A \beta$ antiaggregating properties. The hybrids described by Muñoz-Torreo et al. (33) were formed by the fusion of 6-chlorotacrine, a strong AChE inhibitor, and the previously described tetrahydrobenzonaphthyridine derivatives capable of interacting with both active sites of $A C h E$ and displaying weak $A \beta$ aggregation inhibitory activity. This combination allowed obtaining a group of compounds that can target tau, $A \beta$, and cholinesterases. The most potent derivative $\mathbf{8}$ (Figure 2 ) inhibited $h A C h E$ with an $\mathrm{IC}_{50}$ value of $2.06 \mathrm{nM}$ and $h \mathrm{BuChE}$ with $0.286 \mu \mathrm{M}$, as well as $\mathrm{A} \beta_{42}$ and tau aggregation by $77.5 \%$ and $68.7 \%$, respectively, in recombinant Escherichia coli cells at a concentration of $10 \mu \mathrm{M}$. However, a major disadvantage of this compound is its weak drug-likeness. Similarly, a series of shogaol-huprine hybrids displaying antioxidant properties, in addition to anticholinesterase and antiaggregating activities, was developed, which was characterized by poor drug-likeness (34).

\section{GSK-3 $\beta$ inhibitors with other activities}

The inhibition of tau protein phosphorylation by interaction with GSK-3 $\beta$ is an important tau-centered approach. A group of researchers from the University of Bologna (35) developed a series of 2,4-thiazolidinedione derivatives, which were capable of inhibiting not only GSK-3 $\beta$ but also directly the tau aggregation process. Compound 9 possessing a substituted indole moiety (Figure 2) was the most potent GSK-3 $\beta$ inhibitor $\left(\mathrm{IC}_{50}=0.89 \mu \mathrm{M}\right)$. It inhibited the AcPHF6 aggregation peptide (306VQIVYK311) up to $80 \%$ in a model system at $10 \mu \mathrm{M}$ concentration. 
<smiles>C[n+]1c2c(c(N)c3ccccc31)C(=O)C(=Cc1cccc3ccccc13)CC2</smiles>

inh. tau aggr. $101.8 \%$ at $20 \mu \mathrm{M}$ inh. $A \beta$ aggr. $86.7 \%$ at $20 \mu \mathrm{M}$

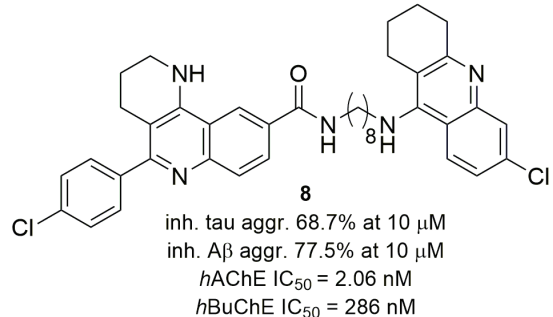

cyclic amid

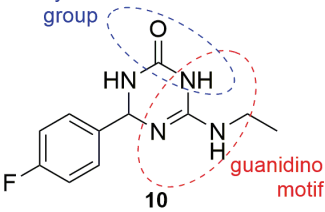

$h$ GSK- $3 \beta$ IC $50=7.11 \mu \mathrm{M}$ $h$ BACE-1 IC $50=16.05 \mu \mathrm{M}$ neuroprotective effect

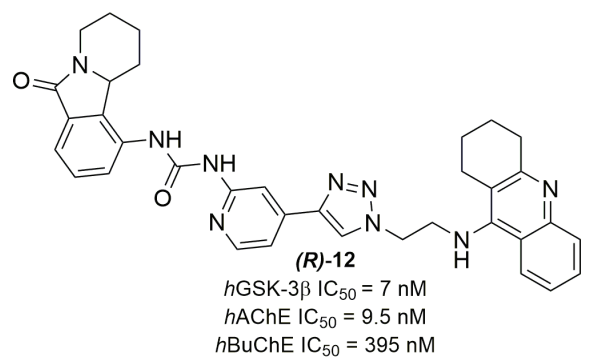<smiles>O=C(/C=C/c1ccc(O)c(O)c1)c1cccnc1</smiles>

14

$h \mathrm{GSK}-3 \beta \mathrm{IC} \mathrm{C}_{50}=24.36 \mu \mathrm{M}$ inh. $A \beta$ aggr. $I C_{50}=9.0 \mu \mathrm{M}$ metal chelating, antioxidant properties<smiles>COc1cc(OCc2ccccn2)ccc1/C=C/c1cc(/C=C/c2ccc3cc[nH]c3c2)[nH]n1</smiles>

inh. tau aggr. $I C_{50}=0.66 \mu \mathrm{M}$ inh. $A \beta$ aggr. $I C_{50}=1.2 \mu \mathrm{M}$ in vivo efficacy<smiles>COc1ccc2c(c1)c(C/C=C1\SC(=O)NC1=O)cn2C</smiles>

$h$ GSK-3 $3 \mathrm{IC}_{50}=0.89 \mu \mathrm{M}$ inh. AcPHF6 aggr. $80 \%$ at $10 \mu \mathrm{M}$

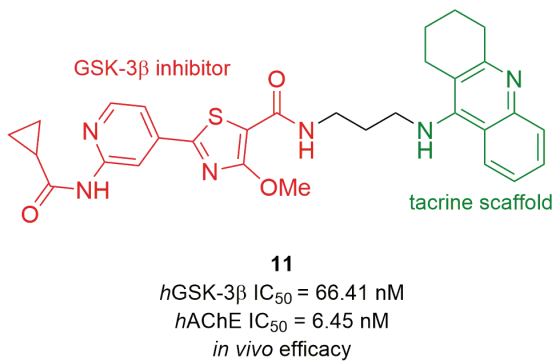

$h \mathrm{GSK}-3 \beta \mathrm{IC} \mathrm{C}_{50}=49 \mathrm{nM}$ metal chelating, antioxidant, $A \beta$ aggregating properties<smiles>O=C1C(=O)N(Cc2ccccc2)c2cc3c(cc2CC1c1cccc2ccccc12)OCO3</smiles>

$h$ GSK- $3 \beta \mathrm{IC}_{50}=6.4 \mu \mathrm{M}$ $h \mathrm{AK} I \mathrm{C}_{50}=13.6 \mu \mathrm{M}$ antioxidant properties

Figure 2. Structures of small molecules targeting tau protein and other targets. 
The BBB permeability of the derivatives revealed by PAMPA, their safety, and ability to inhibit truncated and full-length tau aggregation allow regarding them as tau-centric multitarget agents.

A new disease-modifying strategy that suppressed both amyloid and tau cascades by the inhibition of two enzymes, GSK-3 $\beta$ and BACE-1, was proposed by Bolognesi's group $(36,37)$. A series of triazinones was designed based on two fragments: a guanidine motif interacting with BACE-1 and a cyclic amide group binding to GSK-3 $\beta$. Among the obtained derivatives, compound 10 (Figure 2) was recognized as a novel well-balanced multiple anti-AD agent $\left(\mathrm{IC}_{50} \mathrm{GSK}-3 \beta=\right.$ $7.11 \mu \mathrm{M}, \mathrm{IC}_{50}$ BACE-1 $=16.05 \mu \mathrm{M}$ ) because it showed neuroprotective and neurogenic effects and a good ADME (Adsorption, Distribution, Metabolism, Excretion) profile. Thus, it seems to be a promising lead structure for further development.

The inhibitory activity against GSK-3 $\beta$, together with AChE inhibition, was proposed as a new strategy by Chinese researchers (38). Figure 2 presents the most interesting example (compound $\mathbf{1 1}$ ) for simple combination of tacrine scaffold with the structure of a selective GSK-3 $\beta$ inhibitor using an alkyl linker. Among the ligands developed by the above team, compound 11 exhibited a well-balanced biological profile with the $\mathrm{IC}_{50}$ values in the nanomolar range $\left(\mathrm{IC}_{50} h \mathrm{AChE}=6.5 \mathrm{nM}, \mathrm{IC}_{50} h \mathrm{GSK}-3 \beta=66 \mathrm{nM}\right)$. The efficacy of this dual strategy was verified in the animal model where compound $\mathbf{1 1}$ ameliorated the cognitive decline. Moreover, the examined compound did not demonstrate any hepatotoxicity for tacrine.

Oukoloff et al. (39) also used the same AChE inhibitor fragment for creating hybrids, which showed a similar mechanism of action. They connected tacrine pharmacophore by a linker containing 1,2,3-triazole with the structure of the GSK-3 $\alpha / \beta$ inhibitor valmerin. The in vitro results revealed that compound 12 in the form of an $R$ enantiomer (Figure 2) was the most potent, which exhibited inhibitory potential with an $\mathrm{IC}_{50}$ value of 9.5 and $7 \mathrm{nM}$ for $\mathrm{AChE}$ and GSK-3 $\alpha / \beta$, respectively. Additional advantages of the developed novel tacrine-valmerin multifunctional ligands were low cytotoxicity and good BBB permeability.

The metal hypothesis of $\mathrm{AD}$ indicates that excess levels and dysregulation of biometal ions, such as $\mathrm{Cu}^{2+}, \mathrm{Fe}^{2+}, \mathrm{Zn}^{2+}$, and $\mathrm{Ca}^{2+}$, in the brain cause $\mathrm{A} \beta$ aggregation, generation of reactive oxygen species (ROS), and oxidative stress, leading to cell death (40). Metal chelators are potential anti-AD agents and are also used in the development of multifunctional agents (41). A novel approach based on combing GSK-3 $\beta$ inhibitors with agents exhibiting metal-chelating and $A \beta$-antiaggregating properties was recently presented. The newly formed compounds included 2,3-diaminopyridine derivatives (42) and hydroxy-substituted trans-cinnamoyl derivatives (43). The most promising representative compound 13 from the first group (Figure 2) inhibited the GSK-3 $\beta$ enzyme with an $\mathrm{IC}_{50}$ value of $49 \mathrm{nM}$ and acted as a selective $\mathrm{Cu}^{2+}$ and $\mathrm{Al}^{3+}$ chelator, showing antioxidant and $A \beta$-antiaggregating properties. On the other hand, compound 14 from the second series (Figure 2) exhibited lower inhibitory potency against GSK-3 $\beta$ $\left(\mathrm{IC}_{50}=24.36 \mu \mathrm{M}\right)$, but displayed a broad profile of anti-AD activities.

In turn, two series of compounds, benzoxazinone and indole derivatives, were designed as dual kinase inhibitors (44). Besides inhibiting GSK-3 $\beta$, they targeted human adenosine kinase ( $h \mathrm{AK}$ ), which also induces the development of $\mathrm{AD}$ by 
regulating the level of adenosine and cytoprotective effects. Based on three wellknown $h A K / h G S K-3 \beta$ inhibitors, the structures of novel agents were designed and developed. Among them, 15 (Figure 2) displayed dual kinase inhibitory activity $\left(\mathrm{IC}_{50} h \mathrm{AK}=13.6 \mu \mathrm{M}, \mathrm{IC}_{50} h \mathrm{GSK}-3 \beta=6.4 \mu \mathrm{M}\right)$ with antioxidant and neuroprotective properties, and thus identified as an appropriate lead structure for the development of multifunctional ligands that can exhibit an innovative mechanism of action.

\section{MULTIFUNCTIONAL AGENTS FOCUSING ON SYMPTOMATIC THERAPIES WITH ADDITIONAL BENEFICIAL PROPERTIES}

In the course of Alzheimer's disease, it is important to both treat the causes and symptoms of the disease. Dementia changes in patients are also associated with other disease symptoms, such as depression, anxiety, psychosis, and personality changes. According to the oldest theory of $\mathrm{AD}$, dementia changes and memory disturbances are associated with damage to cholinergic neurotransmission. Other symptoms result from disturbances in other neurotransmitter systems, including GPCRs, such as serotonin, $\mathrm{H}_{3}$ histamine receptors, and the cannabinoid system or with impaired functioning of enzymatic systems such as MAOs. Hence, the design of multifunctional molecules aimed at the treatment of disease symptoms is based on combining the inhibitory activity of cholinesterase with the influence on the other molecular targets mentioned earlier.

\section{Multifunctional ligands influencing serotonin and cholinergic neurotransmission}

Among all GPCRs, serotoninergic receptors are the most attractive as they are targeted for designing MTDLs as potential treatment of AD. Their particularly desired actions are the activation of $5-\mathrm{HT}_{4}$ receptors $\left(5-\mathrm{HT}_{4} \mathrm{Rs}\right)$ and inhibition of 5- $\mathrm{HT}_{6}$ receptors $\left(5-\mathrm{HT}_{6} \mathrm{Rs}\right)$ (45). The first action leads to the modulation of APP metabolism and redirects the protein to a nonamyloid pathway. In turn, 5-HT 6 blockage improves cognitive performance by increasing the release of glutamate, acetylcholine, and catecholamine in the cortical and limbic areas.

The first class of multifunctional ligands formed by combining $5-\mathrm{HT}_{4} \mathrm{Rs}$ with cholinesterases was presented by Dallemagne's research team (46). They described a compound named donecopride (compound 16, Figure 3) as a new preclinical multifunctional drug candidate showing both in vitro AChE inhibitory activity and 5- $\mathrm{HT}_{4} \mathrm{R}$ agonistic potency. Moreover, donecopride also displayed in vivo procognitive and antiamnestic activities in mice. The same research group (47) described novel MTLs with an interesting biological profile, which were capable of restoring cholinergic transmission through the activation of $5-\mathrm{HT}_{4} \mathrm{R}$, blockage of $5-\mathrm{HT}_{6} \mathrm{R}$, and inhibition of AChE. This class of compounds was developed by merging the previously developed dual compound with the benzyl analog of donecopride displaying in vitro $5-\mathrm{HT}_{4} \mathrm{R}$ agonist and $5-\mathrm{HT}_{6} \mathrm{R}$ antagonist properties. The most interesting compound was 17 (Figure 3), a fumaric acid salt exhibiting well-balanced activities toward all the three mentioned targets. Compound 17 was found to act 

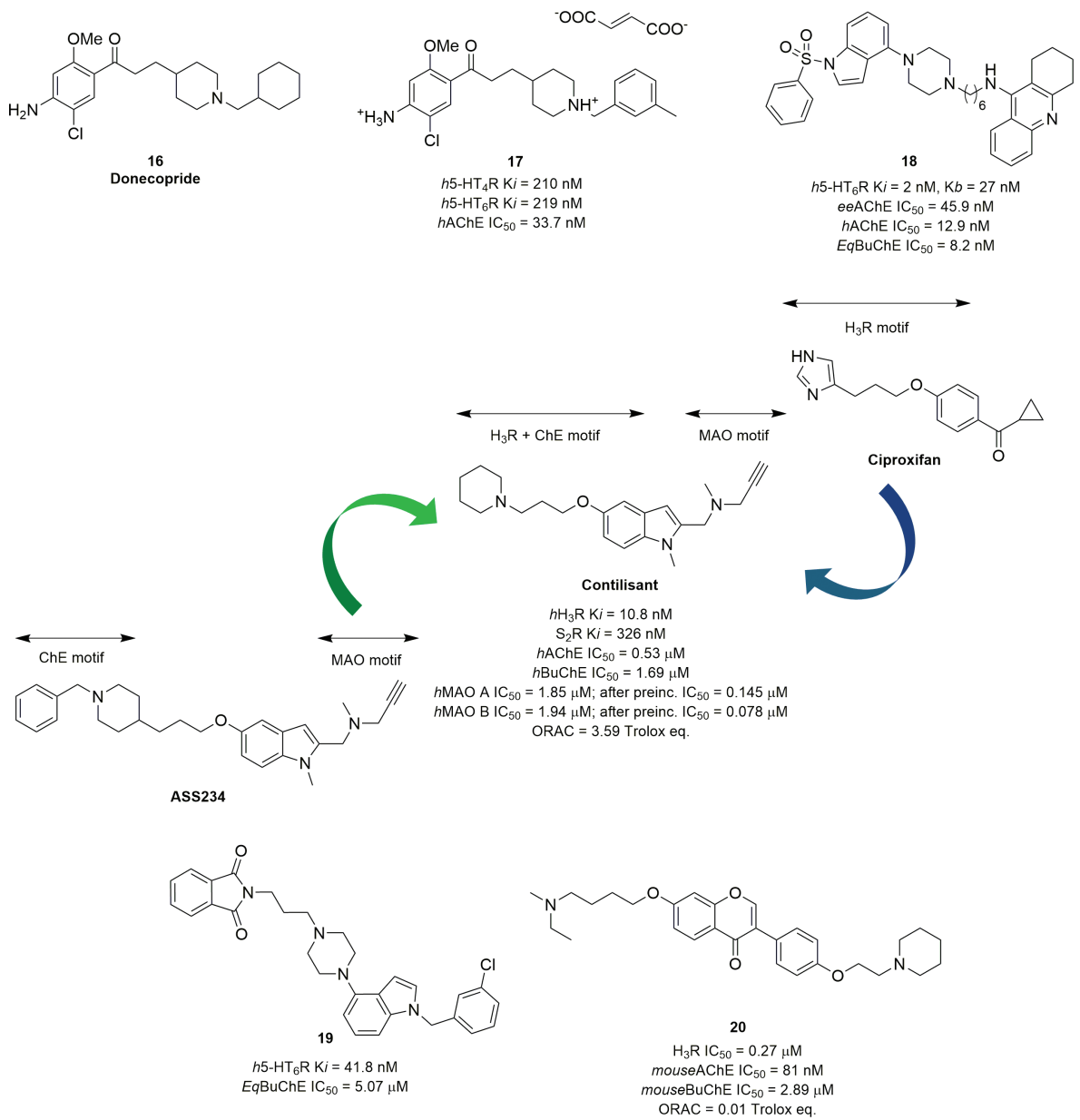

Figure 3. Multifunctional ligands influencing serotonin or histaminergic neurotransmission and cholinesterases.

as a partial agonist of $h 5-\mathrm{HT}_{4} \mathrm{R}(\mathrm{Ki}=210 \mathrm{nM})$, an inverse agonist of $h 5-\mathrm{HT}_{6} \mathrm{R}(\mathrm{Ki}$ $=219 \mathrm{nM})$, and an inhibitor of $h \mathrm{AChE}\left(\mathrm{IC}_{50}=33.7 \mathrm{nM}\right)$. Additionally, the compound was tested in vivo in a model of scopolamine-induced working memory deficit, where it displayed antiamnestic effects at a dose of $0.3 \mathrm{mg} / \mathrm{kg}$.

Several multifunctional ligands based on the combination of pharmacophores that are dedicated to $5-\mathrm{HT}_{6} \mathrm{R}$ blockage and cholinesterase inhibition were developed by Więckowska et al. $(48,49)$. These novel hybrid ligands were obtained by combining the pharmacophores directed against $5-\mathrm{HT}_{6} \mathrm{R}$ (1-(phenylsulfonyl)-4(piperazin-1-yl)-1H-indole) and cholinesterases (tacrine or N-benzylpiperidine analogs). Among them, compound $\mathbf{1 8}$ (Figure 3) was the most interesting as it displayed potent and balanced antagonist activity toward $5-\mathrm{HT}_{6} \mathrm{R}(\mathrm{Ki}=27 \mathrm{nM})$ and inhibitory effect against both cholinesterases $\left(\mathrm{IC}_{50} \mathrm{AChE}=12 \mathrm{nM}, \mathrm{IC}_{50}\right.$ 
$\mathrm{BuChE}=29 \mathrm{nM})$. The compound also showed good in vitro BBB permeability (proved by PAMPA). Additionally, an in vivo study with the use of a scopolamineinduced hyperlocomotion rat model confirmed the central cholinomimetic activity of the compound (48). The further development of this series of hybrids resulted in multifunctional ligands with $A \beta$ antiaggregation properties (49).

Indole-based multifunctional ligands were designed, synthesized, and evaluated for the treatment of $\mathrm{AD}$ as $5-\mathrm{HT}_{6} \mathrm{R}$ blockers with inhibitory abilities toward $e q \mathrm{BuChE}$ and antioxidant properties (50). Based on the biological screening of the 5- $\mathrm{HT}_{6} \mathrm{R}$ antagonists against $\mathrm{BuChE}$, two compounds were selected. In order to improve their BuChE inhibitory activity, structural modifications were introduced in the next stage in the two series of compounds. Of them, ligand 19 (Figure 3) displayed beneficial, dual activity targeting $5-\mathrm{HT}_{6} \mathrm{R}(\mathrm{Ki}=41.8 \mathrm{nM})$ and eqBuChE $\left(\mathrm{IC}_{50}=5.07 \mu \mathrm{M}\right)$, in addition to favorable antioxidant properties that were comparable with the reference ascorbic acid.

\section{Multifunctional ligands combining $\mathrm{H}_{3} \mathrm{R}$ antagonism and cholinesterase inhibition}

Histamine $\mathrm{H}_{3}$ receptor $\left(\mathrm{H}_{3} \mathrm{R}\right)$ belongs to the GPCRs family. In the central nervous system (CNS), $\mathrm{H}_{3} \mathrm{R}$ acts as a presynaptic autoreceptor and is involved in inhibiting the release of histamine and the modulation of other neurotransmitters such as acetylcholine. Numerous in vivo studies have proven that both antagonist and inverse agonists of $\mathrm{H}_{3} \mathrm{R}$ improve cognitive deficits, memory, and spatial orientation (51). Based on their results, $\mathrm{H}_{3} \mathrm{R}$ is frequently chosen as a biological target for anti-AD multifunctional ligands (52-54).

An international multiteam group discovered new multifunctional ligands with a broad and well-balanced spectrum of activities against $\mathrm{H}_{3} \mathrm{R}, \mathrm{AChE}, \mathrm{BuChE}$, and $\mathrm{MAO}-\mathrm{A} / \mathrm{B}(55,56)$. These new indole derivatives were designed by combining the neuroprotectant ASS234 with cholinesterase- and MAO-inhibiting motifs and ciproxifan containing $\mathrm{H}_{3} \mathrm{R}$-blocking and $\mathrm{MAO}$-inhibiting pharmacophore fragments (Figure 3). Among the newly formed hybrids, contilisant was identified as the most promising multifunctional agent. It inhibited $h \mathrm{MAO}-\mathrm{A}\left(\mathrm{IC}_{50}=1.85 \mu \mathrm{M}\right.$, after 30 min of preincubation $\left.\mathrm{IC}_{50}=0.145 \mu \mathrm{M}\right), h \mathrm{MAO}-\mathrm{B}\left(\mathrm{IC}_{50}=1.94 \mu \mathrm{M}\right.$, after $30 \mathrm{~min}$ of preincubation $\left.\mathrm{IC}_{50}=0.078 \mu \mathrm{M}\right), h \mathrm{AChE}\left(\mathrm{IC}_{50}=0.530 \mu \mathrm{M}\right)$, and $h \mathrm{BuChE}\left(\mathrm{IC}_{50}=\right.$ $1.690 \mu \mathrm{M})$, as well as blocked $\mathrm{H}_{3} \mathrm{R}(\mathrm{Ki}=10.8 \mathrm{nM})$. Moreover, contilisant demonstrated in vitro antioxidant neuroprotective effects and the ability to penetrate the BBB in PAMPA. Due to its original in vitro biological profile, contilisant was selected for in vivo studies and tested using the novel object recognition test in mice with LPS-induced cognitive deficit. Based on the excellent in vitro data supported by positive in vivo activity, contilisant was studied further with the aim of exploring new pharmacological properties that may be potentially beneficial for AD therapy (57). The studies revealed another valuable activity of the compound: selective agonistic effect on Sigma 1 receptor $(\mathrm{S} 1 \mathrm{R})(\mathrm{Ki}=65.2 \mathrm{nM})$. S1R is associated with learning and memory processes, and hence, its agonists are used as antiamnestic agents in a variety of pharmacological models, probably due to the improvement of glutamatergic and cholinergic neurotransmissions. Additional in vivo studies including Y-maze and radical arm-maze tasks in mice with cognitive impairment induced by $A \beta_{1-42}$ oligomers showed that contilisant exhibited higher activity in comparison with the 
commonly used anti-AD drug donepezil. Due to its multifunctional profile as well as in vitro activities, which were reflected in in vivo tests, contilisant thus seems to be an interesting multifunctional ligand for further development as a diseasemodifying anti-AD agent (57).

A number of anti-AD multifunctional ligands have been developed based on naturally occurring substances. Wang et al. (58) synthesized a series of multifunctional ligands based on isoflavone, which was recently proven to exhibit inhibitory properties toward cholinesterases. In vitro studies revealed that some of these ligands showed a multifunctional profile including blockage of $\mathrm{H}_{3} \mathrm{R}$, neuroprotective effect, and antineuroinflammatory properties. Among them, compound 20 (Figure 3) is noteworthy since it displayed moderate $\mathrm{H}_{3} \mathrm{R}$ antagonist property $(\mathrm{Ki}=270 \mathrm{nM})$ and potently inhibited $\mathrm{AChE}\left(\mathrm{IC}_{50}=80 \mathrm{nM}\right)$. In addition, the compound 20 demonstrated neuroprotective and antineuroinflammatory properties. The in vivo study also confirmed that it did not induce acute toxicity even at high doses $(1000 \mathrm{mg} / \mathrm{kg}$ ), but penetrated through the BBB into the CNS and caused significant improvements in mice with scopolamine-induced cognitive deficit, which were revealed by passive avoidance test (58).

Ismaili et al. (59) described new small molecules combining activities against three biological targets including $h \mathrm{H}_{3} \mathrm{R}$. The most promising lead showed high affinity toward $h \mathrm{H}_{3} \mathrm{R}(\mathrm{Ki}=0.565 \mu \mathrm{M}), \mathrm{Ca}^{2+}$ channel blockade activity $\left(\mathrm{IC}_{50}=21 \mu \mathrm{M}\right)$, and moderate selective $h \mathrm{BuChE}$ inhibition $\left(\mathrm{IC}_{50}=7.83 \mu \mathrm{M}\right.$ ), besides strong antioxidant properties and ability to restore cognitive impairment induced by LPS.

\section{Multifunctional ligands targeting endocannabinoid system and cholinesterases}

Since the discovery that the activation of cannabinoid receptors $\left(\mathrm{CB}_{1} \mathrm{R}, \mathrm{CB}_{2} \mathrm{R}\right)$ causes a reduction in the production of neurotoxic factors (ROS, proinflammatory mediators) leading to decreased neuroinflammatory processes, the receptors were considered as another biological target in the search for anti-AD agents as well as multipotent ligands $(60,61)$. Consequently, Decker's group (62) developed a series of benzimidazole-based dual-acting ligands that can activate $\mathrm{CB}_{2} \mathrm{R}$ and inhibit BuChE. Among them, the authors highlighted compound 21 as the most promising hybrid (Figure 4) as it activated $h \mathrm{CB}_{2} \mathrm{R}$ with an $\mathrm{IC}_{50}$ value of $0.763 \mu \mathrm{M}$ and $h \mathrm{BuChE}$ with an $\mathrm{IC}_{50}$ value of $1.6 \mu \mathrm{M}$. It is worth noting that this compound 21 was selective over $h \mathrm{CB}_{1} \mathrm{R}$ and $\mathrm{AChE}$. Compound 21 was further evaluated in vivo which revealed that it improved cognitive functions in mice showing neuroinflammation and cognition deficits after $A \beta_{25-35}$ administration at doses ranging from 1 to $3 \mathrm{mg} / \mathrm{kg}$.

In turn, Montanari et al. (63) synthesized multifunctional ligands that indirectly enhanced endocannabinoid signaling by inhibiting fatty acid amide hydrolase (FAAH), an enzyme responsible for the degradation of crucial endocannabinoid signaling molecules: $\mathrm{N}$-arachidonoylethanoloamine and 2-arachidonoyl glycerol. In addition to FAAH, the compounds inhibited cholinesterases. Some of the compounds exhibited very high potencies toward single targets; however, the most interesting MTL was compound 22 (Figure 4). It potently inhibited FAAH $\left(\mathrm{IC}_{50}=\right.$ $157.2 \mathrm{nM}$, after preincubation $\left.\mathrm{IC}_{50}=27.9 \mathrm{nM}\right), h \mathrm{AChE}\left(\mathrm{IC}_{50}=922 \mathrm{nM}\right)$, and $h \mathrm{BuChE}\left(\mathrm{IC}_{50}=42.7 \mathrm{nM}\right)$. 


\section{Enzyme inhibitors-MAO-A/B and cholinoesterases}

MAOs (MAO-A and MAO-B) are the enzymes responsible for the degradation and inactivation of monoamine neurotransmitters. The inhibition of MAOs leads to neuroprotective effects, not only due to an increase in monoaminergic neurotransmission but also due to limitations in the production of neurotoxic substances, which are by-products of a reaction catalyzed by these enzymes. Due to its multiactive nature, the chromone scaffold is commonly applied as a structural motive in the development of multimodal ligands. Based on its structure, Reis et al. (64) reported a series of dual MAO and cholinesterase inhibitors. Among the tested compounds, the most promising was found to be compound 23 (Figure 4), which selectively inhibited $h A C h E\left(\mathrm{IC}_{50}=210 \mathrm{nM}\right)$ over BuChE and nonselectively inhibited both the isoforms of $\mathrm{MAO}\left(\mathrm{IC}_{50} \mathrm{MAO}-\mathrm{A}=0.94 \mu \mathrm{M}, \mathrm{IC}_{50} \mathrm{MAO}-\mathrm{B}=3.81 \mu \mathrm{M}\right)$. Moreover, the additional pharmacokinetic and toxicological studies of compound 23 showed its lack of cytotoxicity at a concentration below $25 \mu \mathrm{M}$, and PAMPA predicted its penetration through the BBB. Thus, the established well-balanced activities, low toxicity, and predicted permeability of the tested compound make them interesting multifunctional ligands for AD therapy.

Another group of dual inhibitors of MAOs and cholinesterases was developed by connecting $N$-benzylpiperidine fragment derived from donepezil with di-tert-butylated hydroxytoluene, which is a fragment responsible for antioxidant, anticancer, and anti-inflammatory properties in numerous compounds (65). These inhibitors were analyzed by studies divided into two parts: the first aimed to find an appropriate linker to connect the two pharmacophores and the second aimed to decorate the aromatic ring of the benzylpiperidine scaffold. Among the tested compounds, 24 was recognized as a double $\mathrm{AChE}\left(\mathrm{IC}_{50} e e \mathrm{AChE}=75 \mathrm{nM}, \mathrm{IC}_{50} h \mathrm{AChE}=750 \mathrm{nM}\right)$ and MAO-B $\left(\mathrm{IC}_{50}=7.5 \mu \mathrm{M}\right)$ inhibitor with noticeable antioxidant properties and

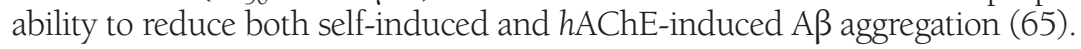

\section{MULTIFUNCTIONAL AGENTS FOCUSING ON VARIOUS DISEASE-MODIFYING AND SYMPTOMATIC THERAPIES}

The complexity of AD etiopathogenesis forced a search for new biological targets in the CNS and even beyond. Among the numerous molecular targets discovered, some have been used to create multifunctional ligands.

In pathological conditions, S1R modulates regulatory proteins, restores calcium homeostasis, and controls the production of ROS, thereby contributing to the overall neuroprotection effect (66). Based on their previous study, Rui et al. (67) developed multifunctional agents capable of modulating S1R and inhibiting AChE. The chemical structure of the new multifunctional ligands was developed through an interesting combination of RRC-33 (S1R agonist), curcumin (having antioxidant properties), and donepezil. The newly developed compounds exhibited a high affinity to S1R, but very weak AChE inhibitory properties. Among them, compound 25 (Figure 4) showed binding affinity to S1R with a Ki value of $15 \mathrm{nM}$; however, it inhibited AChE only by $64.80 \%$ at a concentration of $50 \mu \mathrm{M}$. Its neuroprotective effect associated with S1R modulation was confirmed by the neurite outgrowth observed in the dorsal root ganglia in the in vitro model (67). 


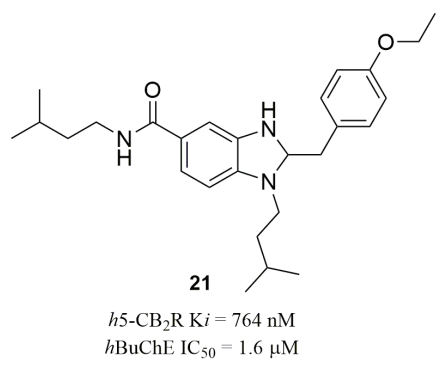<smiles>Cc1ccc(NC(=O)c2cc(=O)c3cc(/C=C/C(=O)OCCN(C)C)ccc3o2)cc1</smiles>

23

$h \mathrm{AChE} \mathrm{IC}_{50}=0.21 \mu \mathrm{M}$ $h \mathrm{MAO} \mathrm{A} \mathrm{IC} 5_{50}=0.94 \mu \mathrm{M}$ $h \mathrm{MAO} \mathrm{B} \mathrm{IC} 50=3.81 \mu \mathrm{M}$<smiles>O=C(NCCc1ccccc1)Oc1cccc(Cn2cc(COc3ccc4ccc(=O)oc4c3)nn2)c1</smiles>

22

$h \mathrm{AChE} \mathrm{IC} \mathrm{I}_{50}=922 \mathrm{nM}$ $h \mathrm{BuChE} \mathrm{IC}_{50}=43 \mathrm{nM}$ $r$ FAAH $\mathrm{IC}_{50}=157 \mathrm{nM}$; after preinc. $\mathrm{IC}_{50}=28 \mathrm{nM}$

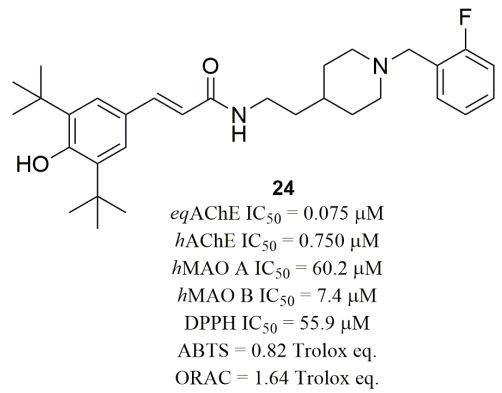<smiles>COC(=O)C(C)c1ccc(-c2ccc(CNc3cc(N(C)C)ccc3O)cc2)c(F)c1</smiles>

25

$\mathrm{S} \mathrm{R} \mathrm{K}_{i}=15 \mathrm{nM}$ $\mathrm{S} 2 \mathrm{R} \mathrm{K}_{i}=462 \mathrm{nM}$ $e e \mathrm{AChE}$ inh. $=64.80 \%$ at $50 \mu \mathrm{M}$

$$
\begin{gathered}
26 \\
\text { MAO B IC } 50=10.30 \mu \mathrm{M} \\
\text { ORAC }=2.44 \text { Trolox eq. } \\
\text { self-ind. } \mathrm{A} \beta_{1-42} \text { aggr. inh. }=96.33 \% \text { at } 25 \mu \mathrm{M} \\
\mathrm{Cu}^{2+} \text {-ind. } \mathrm{A} \beta_{1-42} \text { aggr. inh. }=84.33 \% \text { at } 25 \mu \mathrm{M} \\
\text { dissagreagtion of } \mathrm{A} \beta_{1-42} \text { fibrils }=91.12 \% \text { at } 25 \mu \mathrm{M}
\end{gathered}
$$<smiles>O=C(Nc1ccc(O)c2[nH+]cccc12)c1ccc(OC(F)F)c(OCC2CC2)c1</smiles>

27

PDE4D2 $\mathrm{IC}_{50}=0.399 \mu \mathrm{M}$ ORAC $=0.60$ Trolox eq.

Figure 4. Multifunctional agents focusing on various targets.

Interesting biological activities were also presented by flurbiprofen-clioquinol hybrids (68). Flurbiprofen is a known potent nonsteroidal anti-inflammatory drug, which also inhibits platelet aggregation and $A \beta$ aggregation and reduces tau phosphorylation. On the other hand, clioquinol is a metal chelator with proven antioxidant properties. Among the obtained hybrids, compound 26 (Figure 4) was able to inhibit both self-induced and $\mathrm{Cu}^{2+}$-induced $\mathrm{A} \beta$ aggregation and MAO-B. In addition, it presented biometal-chelating abilities as well as antioxidant and antineuroinflammatory activities and appropriate BBB permeability.

In turn, Hu et al. (69) developed a novel group of multifunctional compounds by combining clioquinol with rolipram or roflumilast. These compounds inhibited phosphodiesterase 4D (PDE4D), an enzyme participating in the process of memory consolidation and long-term potentiation. The most interesting of them 
was compound 27 (Figure 4), which inhibited not only the PDE4D with an $\mathrm{IC}_{50}$ value of $0.399 \mu \mathrm{M}$ but also the metal-induced aggregation of $\mathrm{A} \beta$, chelated metal ions, and exhibited antioxidant properties (ORAC [oxygen radical absorbance capacity] $=0.60$ Trolox eq.). In addition to in vitro activity, compound 27 showed in vivo activity by demonstrating procognitive effects in the Morris water-maze test.

Another example of multifunctional compounds is hybrids formed by the combination of pharmacophore cyclooxygenase-2 and 15-lipoxygenase enzymes with the structure of tacrine (70). These compounds are endowed with antineuroinflammatory and anticholinesterase activities.

\section{CONCLUSION}

The lack of an effective treatment or DMT capable of influencing the causes of AD has led to a constant need to search for new solutions and drugs. Undoubtedly, an important issue here is the identification of new disease biomarkers, which can indicate early enough the pathological changes in the brain that may lead to irreversible processes and symptoms over time. The search for new anti-AD agents is challenging due to the complexity of the disease and the corresponding lack of appropriate animal models useful in preclinical studies. In addition, there is a need for properly planned clinical trials to demonstrate the effectiveness of the drugs. These problems concern small molecules targeting single biological target as well as combination treatment and multifunctional compounds. The clinical trials of combination therapy for AD focus on combining a cholinesterase inhibitor or memantine with other medications having various therapeutic indications. In this context, multifunctional ligands seem to be a much better strategy as they combine effects aimed at both causal and symptomatic treatment of the disease.

The examples presented in this chapter show that the search for new anti-AD drugs is based on the combination of pharmacophores acting not only on cholinesterases and $A \beta$ aggregation but also on tau protein aggregation (GSK-3 $\beta$ inhibitors), neuroinflammation, and antioxidation. The ligands that regulate the influence on GPCRs or MAOs are particularly interesting, taking into account that the symptoms of depression or other mental disorders often coexist in AD. This may indicate that the proper design of a multifunctional molecule can facilitate the discovery of an effective therapy for this devastating disease.

Acknowledgment: This work was supported by the National Science Center of Poland (grant UMO-2016/21/B/NZ7/01744).

Conflict of Interest: The authors declare no potential conflicts of interest with respect to research, authorship, and/or publication of this chapter.

Copyright and Permission Statement: To the best of our knowledge, the materials included in this chapter do not violate copyright laws. All original sources have been appropriately acknowledged and/or referenced. Where relevant, appropriate permissions have been obtained from the original copyright holder(s). 


\section{REFERENCES}

1. Querfurth HW, LaFerla FM. Alzheimer's disease. N Engl J Med. 2010;362(4):329-44. http://dx.doi. org/10.1056/NEJMra0909142

2. Carreiras M, Mendes E, Perry M, Francisco A, Marco-Contelles J. The multifactorial nature of Alzheimer's disease for developing potential therapeutics. Curr Top Med Chem. 2014;13(15): 1745-70. http://dx.doi.org/10.2174/15680266113139990135

3. Morsy A, Trippier PC. Current and emerging pharmacological targets for the treatment of Alzheimer's disease. J Alzheimers Dis. 2019;72(Suppl 1):S145-76. http://dx.doi.org/10.3233/JAD-190744

4. Peters J-U. Polypharmacology-Foe or friend? J Med Chem. 2013;56(22):8955-71. http://dx.doi. org/10.1021/jm400856t

5. Morphy R, Rankovic Z. Designing multiple ligands-Medicinal chemistry strategies and challenges. Curr Pharm Des. 2009;15(6):587-600. http://dx.doi.org/10.2174/138161209787315594

6. Bansal Y, Silakari O. Multifunctional compounds: Smart molecules for multifactorial diseases. Eur J Med Chem. 2014;76:31-42. http://dx.doi.org/10.1016/j.ejmech.2014.01.060

7. Proschak E, Stark H, Merk D. Polypharmacology by design: A medicinal chemist's perspective on multitargeting compounds. J Med Chem. 2019;62(2):420-44. http://dx.doi.org/10.1021/acs. jmedchem.8b00760

8. Cummings JL, Tong G, Ballard C. Treatment combinations for Alzheimer's disease: Current and future pharmacotherapy options. J Alzheimers Dis. 2019;67(3):779-94. http://dx.doi.org/10.3233/ JAD-180766

9. Deardorff WJ, Grossberg G. A fixed-dose combination of memantine extended-release and donepezil in the treatment of moderate-to-severe Alzheimer's disease. Drug Des Devel Ther. 2016;10:3267-79. http://dx.doi.org/10.2147/DDDT.S86463

10. Morphy R, Rankovic Z. Designed multiple ligands. An emerging drug discovery paradigm. J Med Chem. 2005;48(21):6523-43. http://dx.doi.org/10.1021/jm058225d

11. Prati F, Cavalli A, Bolognesi ML. Navigating the chemical space of multitarget-directed ligands: From hybrids to fragments in Alzheimer's disease. Molecules. 2016;21(4):466. http://dx.doi.org/10.3390/ molecules 21040466

12. Oset-Gasque MJ, Marco-Contelles J. Alzheimer's disease, the "one-molecule, one-target" paradigm, and the multitarget directed ligand approach. ACS Chem Neurosci. 2018;9(3):401-3. http://dx.doi. org/10.1021/acschemneuro.8b00069

13. Benek O, Korabecny J, Soukup O. A perspective on multi-target drugs for Alzheimer's disease. Trends Pharmacol Sci. 2020;41:1-12. http://dx.doi.org/10.1016/j.tips.2020.04.008

14. Weinreb O, Amit T, Bar-Am O, Youdim MB. Ladostigil: A novel multimodal neuroprotective drug with cholinesterase and brain-selective monoamine oxidase inhibitory activities for Alzheimer's disease treatment. Curr Drug Targets. 2012;13(4):483-94. http://dx.doi.org/ $10.2174 / 138945012799499794$

15. Zhang P, Xu S, Zhu Z, Xu J. Multi-target design strategies for the improved treatment of Alzheimer's disease. Eur J Med Chem. 2019;176:228-47. http://dx.doi.org/10.1016/j.ejmech.2019.05.020

16. Viayna E, Sabate R, Muñoz-Torrero D. Dual inhibitors of $\beta$-amyloid aggregation and acetylcholinesterase as multi-target anti-Alzheimer drug candidates. Curr Top Med Chem. 2013;13(15):1820-42. http://dx.doi.org/10.2174/15680266113139990139

17. Guzior N, Wieckowska A, Panek D, Malawska B. Recent development of multifunctional agents as potential drug candidates for the treatment of Alzheimer's disease. Curr Med Chem. 2015;22(3): 373-404. http://dx.doi.org/10.2174/0929867321666141106122628

18. Ismaili L, Refouvelet B, Benchekroun M, Brogi S, Brindisi M, Gemma S, et al. Multitarget compounds bearing tacrine- and donepezil-like structural and functional motifs for the potential treatment of Alzheimer's disease. Prog Neurobiol. 2016;151:4-34. http://dx.doi.org/10.1016/j.pneurobio.2015.12.003

19. Li Q, He S, Chen Y, Feng F, Qu W, Sun H. Donepezil-based multi-functional cholinesterase inhibitors for treatment of Alzheimer's disease. Eur J Med Chem. 2018;158:463-77. http://dx.doi.org/10.1016/j. ejmech.2018.09.031 
20. Panek D, Wichur T, Godyń J, Pasieka A, Malawska B. Advances toward multifunctional cholinesterase and $\beta$-amyloid aggregation inhibitors. Future Med Chem. 2017;9:1835-54. http://dx.doi. org/10.4155/fmc-2017-0094

21. Selkoe DJ, Hardy J. The amyloid hypothesis of Alzheimer's disease at 25 years. EMBO Mol Med. 2016;8(6):595-608. http://dx.doi.org/10.15252/emmm.201606210

22. Cummings J, Lee G, Ritter A, Sabbagh M, Zhong K. Alzheimer's disease drug development pipeline: 2019. Alzheimers Dement Transl Res Clin Interv. 2019;5:272-93. http://dx.doi.org/10.1016/j. trci.2019.05.008

23. Sharma P, Tripathi A, Tripathi PN, Prajapati SK, Seth A, Tripathi MK, et al. Design and development of multitarget-directed N-Benzylpiperidine analogs as potential candidates for the treatment of Alzheimer's disease. Eur J Med Chem. 2019;167:510-24. http://dx.doi.org/10.1016/j. ejmech.2019.02.030

24. Panek D, Więckowska A, Jończyk J, Godyń J, Bajda M, Wichur T, et al. Design, synthesis, and biological evaluation of 1-benzylamino-2-hydroxyalkyl derivatives as new potential disease-modifying multifunctional anti-Alzheimer's agents. ACS Chem Neurosci. 2018;9(5):1074-94. http://dx.doi. org/10.1021/acschemneuro.7b00461

25. Fang Y, Zhou H, Gu Q, Xu J. Synthesis and evaluation of tetrahydroisoquinoline-benzimidazole hybrids as multifunctional agents for the treatment of Alzheimer's disease. Eur J Med Chem. 2019;167:133-45. http://dx.doi.org/10.1016/j.ejmech.2019.02.008

26. Cai P, Fang SQ, Yang XL, Wu JJ, Liu QH, Hong H, et al. Rational design and multibiological profiling of novel donepezil-trolox hybrids against Alzheimer's disease, with cholinergic, antioxidant, neuroprotective, and cognition enhancing properties. ACS Chem Neurosci. 2017;8(11):2496-511. http:// dx.doi.org/10.1021/acschemneuro.7b00257

27. Xu P, Zhang M, Sheng R, Ma Y. Synthesis and biological evaluation of deferiprone-resveratrol hybrids as antioxidants, $A \beta_{1-42}$ aggregation inhibitors and metal-chelating agents for Alzheimer's disease. Eur J Med Chem. 2017;127:174-86. http://dx.doi.org/10.1016/j.ejmech.2016.12.045

28. Naseri NN, Wang H, Guo J, Sharma M, Luo W. The complexity of tau in Alzheimer's disease. Neurosci Lett. 2019;705:183-94. http://dx.doi.org/10.1016/j.neulet.2019.04.022

29. Congdon EE, Sigurdsson EM. Tau-targeting therapies for Alzheimer disease. Nat Rev Neurol. 2018; 14(7):399-415. http://dx.doi.org/10.1038/s41582-018-0013-z

30. Lv P, Xia CL, Wang N, Liu ZQ, Huang ZS, Huang SL. Synthesis and evaluation of 1,2,3,4-tetrahydro1-acridone analogues as potential dual inhibitors for amyloid-beta and tau aggregation. Bioorg Med Chem. 2018;26(16):4693-705. http://dx.doi.org/10.1016/j.bmc.2018.08.007

31. Okuda M, Hijikuro I, Fujita Y, Teruya T, Kawakami H, Takahashi T, et al. Design and synthesis of curcumin derivatives as tau and amyloid $\beta$ dual aggregation inhibitors. Bioorg Med Chem Lett. 2016;26(20):5024-8. http://dx.doi.org/10.1016/j.bmcl.2016.08.092

32. Okuda M, Fujita Y, Hijikuro I, Wada M, Uemura T, Kobayashi Y, et al. PE859, a novel curcumin derivative, inhibits amyloid- $\beta$ and tau aggregation, and ameliorates cognitive dysfunction in senescence-accelerated mouse prone 8. J Alzheimers Dis. 2017;59(1):313-28. http://dx.doi.org/10.3233/JAD-161017

33. Muñoz-Torreo D, Di Pietro O, Pérez-Areales FJ, Juárez-Jiménez J, Espargaró A, Clos MV, Pérez B, et al. Tetrahydrobenzo[h][1,6]naphthyridine-6-chlorotacrine hybrids as a new family of anti-Alzheimer agents targeting $\beta$-amyloid, tau, and cholinesterase pathologies. Eur J Med Chem. 2014;84:107-17. http://dx.doi.org/10.1016/j.ejmech.2014.07.021

34. Pérez-Areales FJ, Di Pietro O, Espargaró A, Vallverdú-Queralt A, Galdeano C, Ragusa IM, et al. Shogaol-huprine hybrids: Dual antioxidant and anticholinesterase agents with $\beta$-amyloid and tau anti-aggregating properties. Bioorg Med Chem. 2014;22(19):5298-307. http://dx.doi.org/10.1016/j. bmc.2014.07.053

35. Gandini A, Bartolini M, Tedesco D, Martinez-Gonzalez L, Roca C, Campillo NE, et al. Tau-centric multitarget approach for Alzheimer's disease: Development of first-in-class dual glycogen synthase kinase $3 \beta$ and tau-aggregation inhibitors. J Med Chem. 2018;61(17):7640-56. http://dx.doi.org/10.1021/ acs.jmedchem.8b00610

36. Prati F, De Simone A, Bisignano P, Armirotti A, Summa M, Pizzirani D, et al. Multitarget drug discovery for Alzheimer's disease: Triazinones as BACE-1 and GSK-3 $\beta$ inhibitors. Angew Chem Int Ed. 2015;54(5):1578-82. http://dx.doi.org/10.1002/anie.201410456 
37. Prati F, De Simone A, Armirotti A, Summa M, Pizzirani D, Scarpelli R, et al. 3,4-Dihydro-1,3,5-triazin$2(1 \mathrm{H})$-ones as the first dual BACE-1/GSK-3 $\beta$ fragment hits against Alzheimer's disease. ACS Chem Neurosci. 2015;6(10):1665-82. http://dx.doi.org/10.1021/acschemneuro.5b00121

38. Jiang XY, Chen TK, Zhou JT, He SY, Yang HY, Chen Y, et al. Dual GSK-3ß/AChE inhibitors as a new strategy for multitargeting anti-Alzheimer's disease drug discovery. ACS Med Chem Lett. 2018;9(3):171-6. http://dx.doi.org/10.1021/acsmedchemlett.7b00463

39. Oukoloff K, Coquelle N, Bartolini M, Naldi M, Le Guevel R, Bach S, et al. Design, biological evaluation and X-ray crystallography of nanomolar multifunctional ligands targeting simultaneously acetylcholinesterase and glycogen synthase kinase-3. Eur J Med Chem. 2019;168:58-77. http://dx.doi. org/10.1016/j.ejmech.2018.12.063

40. Kepp KP. Bioinorganic chemistry of Alzheimer's disease. Chem Rev. 2012;112(10):5193-239. http:// dx.doi.org/10.1021/cr300009x

41. Savelieff MG, Nam G, Kang J, Lee HJ, Lee M, Lim MH. Development of multifunctional molecules as potential therapeutic candidates for Alzheimer's disease, Parkinson's disease, and amyotrophic lateral sclerosis in the last decade. Chem Rev. 2018;119(2):1221-322. http://dx.doi.org/10.1021/acs. chemrev.8b00138

42. Shi XL, Wu J-D, Liu P, Liu ZP. Synthesis and evaluation of novel GSK-3ß inhibitors as multifunctional agents against Alzheimer's disease. Eur J Med Chem. 2019;167:211-25. http://dx.doi.org/10.1016/j. ejmech.2019.02.001

43. De Simone A, Bartolini M, Baschieri A, Apperley KYP, Chen HH, Guardigni M, et al. Hydroxysubstituted trans-cinnamoyl derivatives as multifunctional tools in the context of Alzheimer's disease. Eur J Med Chem. 2017;139:378-89. http://dx.doi.org/10.1016/j.ejmech.2017.07.058

44. Brogi S, Ramunno A, Savi L, Chemi G, Alfano G, Pecorelli A, et al. First dual AK/GSK-3ß inhibitors endowed with antioxidant properties as multifunctional, potential neuroprotective agents. Eur J Med Chem. 2017;138:438-57. http://dx.doi.org/10.1016/j.ejmech.2017.06.017

45. Claeysen S, Bockaert J, Giannoni P. Serotonin: A new hope in Alzheimer's disease? ACS Chem Neurosci. 2015;6(7):940-3. http://dx.doi.org/10.1021/acschemneuro.5b00135

46. Rochais C, Lecoutey C, Gaven F, Giannoni P, Hamidouche K, Hedou D, et al. Novel multitargetdirected ligands (MTDLs) with acetylcholinesterase (AChE) inhibitory and serotonergic subtype 4 receptor (5-HT4R) agonist activities as potential agents against Alzheimer's disease: The design of donecopride. J Med Chem. 2015;58(7):3172-87. http://dx.doi.org/10.1021/acs.jmedchem.5b00115

47. Hatat B, Yahiaoui S, Lecoutey C, Davis A, Freret T, Boulouard M, et al. A novel in vivo anti-amnesic agent, specially designed to express both acetylcholinesterase (AChE) inhibitory, serotonergic subtype 4 receptor (5-HT4R) agonist and serotonergic subtype 6 receptor (5-HT6R) inverse agonist activities, with a potential inter. Front Aging Neurosci. 2019;11:1-14. http://dx.doi.org/10.3389/ fnagi.2019.00148

48. Więckowska A, Kołaczkowski M, Bucki A, Godyń J, Marcinkowska M, Więckowski K, et al. Novel multi-target-directed ligands for Alzheimer's disease: Combining cholinesterase inhibitors and 5-HT6 receptor antagonists. Design, synthesis and biological evaluation. Eur J Med Chem. 2016;124:63-81. http://dx.doi.org/10.1016/j.ejmech.2016.08.016

49. Więckowska A, Wichur T, Godyń J, Bucki A, Marcinkowska M, Siwek A, et al. Novel multitarget-directed ligands aiming at symptoms and causes of Alzheimer's disease. ACS Chem Neurosci. 2018;9(5):1195-214. http://dx.doi.org/10.1021/acschemneuro.8b00024

50. Marcinkowska M, Bucki A, Panek D, Siwek A, Fajkis N, Bednarski M, et al. Anti-Alzheimer's multitarget-directed ligands with serotonin 5-HT6 antagonist, butyrylcholinesterase inhibitory, and antioxidant activity. Arch Pharm (Weinheim). 2019;352(7):e1900041. http://dx.doi.org/10.1002/ $\operatorname{ardp} .201900041$

51. Sadek B, Saad A, Sadeq A, Jalal F, Stark H. Histamine H3 receptor as a potential target for cognitive symptoms in neuropsychiatric diseases. Behav Brain Res. 2016;312:415-30. http://dx.doi. org/10.1016/j.bbr.2016.06.051

52. Darras FH, Pockes S, Huang G, Wehle S, Strasser A, Wittmann HJ, et al. Synthesis, biological evaluation, and computational studies of Tri- and tetracyclic nitrogen-bridgehead compounds as potent dual-acting AChE inhibitors and h H3 receptor antagonists. ACS Chem Neurosci. 2014;5(3):225-42. http://dx.doi.org/10.1021/cn4002126 
53. Łażewska D, Jończyk J, Bajda M, Szałaj N, Więckowska A, Panek D, et al. Cholinesterase inhibitory activity of chlorophenoxy derivatives-Histamine H3 receptor ligands. Bioorg Med Chem Lett. 2016;26(16):4140-5. http://dx.doi.org/10.1016/j.bmcl.2016.04.054

54. Bajda M, Łażewska D, Godyń J, Zaręba P, Kuder K, Hagenow S, et al. Search for new multi-target compounds against Alzheimer's disease among histamine $\mathrm{H} 3$ receptor ligands. Eur J Med Chem. 2020;185:111785. http://dx.doi.org/10.1016/j.ejmech.2019.111785

55. Bautista-Aguilera ÓM, Hagenow S, Palomino-Antolin A, Farré-Alins V, Ismaili L, Joffrin PL, et al. Multitarget-directed ligands combining cholinesterase and monoamine oxidase inhibition with histamine $\mathrm{H}_{3} \mathrm{R}$ antagonism for neurodegenerative diseases. Angew Chemie Int Ed Engl. 2017;56(41):12765-9. http://dx.doi.org/10.1002/anie.201706072

56. Romero A, Marco-Contelles J, Ramos E. Highlights of ASS234: A novel and promising therapeutic agent for Alzheimer's disease therapy. Neural Regen Res. 2020;15(1):30-5. http://dx.doi.org/ 10.4103/1673-5374.262679

57. Bautista-Aguilera ÓM, Budni J, Mina F, Medeiros EB, Deuther-Conrad W, Entrena JM, et al. Contilisant, a tetratarget small molecule for Alzheimer's disease therapy combining cholinesterase, monoamine oxidase inhibition, and H3R antagonism with S1R agonism profile. J Med Chem. 2018;61(15): 6937-43. http://dx.doi.org/10.1021/acs.jmedchem.8b00848

58. Wang D, Hu M, Li X, Zhang D, Chen C, Fu J, et al. Design, synthesis, and evaluation of isoflavone analogs as multifunctional agents for the treatment of Alzheimer's disease. Eur J Med Chem. 2019;168:207-20. http://dx.doi.org/10.1016/j.ejmech.2019.02.053

59. Ismaili L, Malek R, Arribas RL, Palomino-Antolin A, Totoson P, Demougeot C, Kobrlova T, et al. New dual small molecules for Alzheimer's disease therapy combining histamine H3 receptor (H3R) antagonism and calcium channels blockade with additional cholinesterase inhibition. J Med Chem. 2019;62(24):11416-22. http://dx.doi.org/10.1021/acs.jmedchem.9b00937

60. Rizzo S, Tarozzi A, Bartolini M, Da Costa G, Bisi A, Gobbi S, et al. 2-Arylbenzofuran-based molecules as multipotent Alzheimer's disease modifying agents. Eur J Med Chem. 2012;58:519-32. http:// dx.doi.org/10.1016/j.ejmech.2012.10.045

61. González-Naranjo P, Pérez-Macias N, Campillo NE, Pérez C, Arán VJ, Girón R, et al. Cannabinoid agonists showing BuChE inhibition as potential therapeutic agents for Alzheimer's disease. Eur J Med Chem. 2014;73:56-72. http://dx.doi.org/10.1016/j.ejmech.2013.11.026

62. Dolles D, Hoffmann M, Gunesch S, Marinelli O, Möller J, Santoni G, et al. Structure-activity relationships and computational investigations into the development of potent and balanced dual-acting butyrylcholinesterase inhibitors and human cannabinoid receptor 2 ligands with pro-cognitive in vivo profiles. J Med Chem. 2018;61(4):1646-63. http://dx.doi.org/10.1021/acs.jmedchem.7b01760

63. Montanari S, Scalvini L, Bartolini M, Belluti F, Gobbi S, Andrisano V, et al. Fatty acid amide hydrolase (FAAH), acetylcholinesterase (AChE), and butyrylcholinesterase (BuChE): Networked targets for the development of carbamates as potential anti-Alzheimer's disease agents. J Med Chem. 2016;59(13):6387-406. http://dx.doi.org/10.1021/acs.jmedchem.6b00609

64. Reis J, Cagide F, Valencia ME, Teixeira J, Bagetta D, Pérez C, et al. Multi-target-directed ligands for Alzheimer's disease: Discovery of chromone-based monoamine oxidase/cholinesterase inhibitors. Eur J Med Chem. 2018;158:781-800. http://dx.doi.org/10.1016/j.ejmech.2018.07.056

65. Cai P, Fang SQ, Yang HL, Yang XL, Liu QH, Kong LY, et al. Donepezil-butylated hydroxytoluene (BHT) hybrids as anti-Alzheimer's disease agents with cholinergic, antioxidant, and neuroprotective properties. Eur J Med Chem. 2018;157:161-76. http://dx.doi.org/10.1016/j.ejmech.2018.08.005

66. Ryskamp DA, Korban S, Zhemkov V, Kraskovskaya N, Bezprozvanny I. Neuronal sigma-1 receptors: Signaling functions and protective roles in neurodegenerative diseases. Front Neurosci. 2019;13:862. http://dx.doi.org/10.3389/fnins.2019.00862

67. Rui M, Rossino G, Coniglio S, Monteleone S, Scuteri A, Malacrida A, et al. Identification of dual Sigmal receptor modulators/acetylcholinesterase inhibitors with antioxidant and neurotrophic properties, as neuroprotective agents. Eur J Med Chem. 2018;158:353-70. http://dx.doi.org/10.1016/j. ejmech.2018.09.010

68. Yang Z, Song Q, Cao Z, Yu G, Liu Z, Tan Z, et al. Design, synthesis and evaluation of flurbiprofenclioquinol hybrids as multitarget-directed ligands against Alzheimer's disease. Bioorg Med Chem. 2020;28(7):115374. http://dx.doi.org/10.1016/j.bmc.2020.115374 
69. Hu J, Pan T, An B, Li Z, Li X, Huang L. Synthesis and evaluation of clioquinol-rolipram/roflumilast hybrids as multitarget-directed ligands for the treatment of Alzheimer's disease. Eur J Med Chem. 2019;163:512-26. http://dx.doi.org/10.1016/j.ejmech.2018.12.013

70. AlFadly ED, Elzahhar PA, Tramarin A, Elkazaz S, Shaltout H, Abu-Serie MM, et al. Tackling neuroinflammation and cholinergic deficit in Alzheimer's disease: Multi-target inhibitors of cholinesterases, cyclooxygenase-2 and 15-lipoxygenase. Eur J Med Chem. 2019;167:161-86. http://dx.doi. org/10.1016/j.ejmech.2019.02.012 
